\title{
The Effect of Literature Circles on Text Analysis and Reading Desire
}

\author{
Halit Karatay ${ }^{1}$ \\ ${ }^{1}$ Halit Karatay, Abant İzzet Baysal University, Faculty of Education, Department of Turkish Teacher Education, \\ Turkey \\ Correspondence: Halit Karatay, Associate Professor, Abant İzzet Baysal University, Faculty of Education, \\ Department of Turkish Teacher Education, TURKEY. Tel: 90-374-254-1000-1635, E-mail: karatay_h@ibu.edu.tr
}

Received: July 26, 2017

doi:10.5430/ijhe.v6n5p65
Accepted: September 18, 2017

Online Published: September 19, 2017

URL: https://doi.org/10.5430/ijhe.v6n5p65

\begin{abstract}
In order to make teaching activities more appealing, different techniques and strategies have been constantly employed. This study utilized the strategy of "literature circles" to improve the text-analysis skills, reading desires, and interests of prospective teachers of Turkish. "Literature circles" was not chosen to be used as the sole strategy throughout the entire weekly class hours; instead, it was used only for one class hour of every weekly four-hour classes, being complementary to and supportive of other teaching activities. The study was carried out as action research. A total of 92 third-year students in two sections of the department of Turkish Education voluntarily participated in the study. In order to improve the students" book reviewing skills and reading interests, "literature circles" was implemented for a period of 12 weeks for one class hour. At the end of the implementation of "literature circles" when the students" reading comprehension pre-test and post-test scores were compared, a significant difference was observed. Based on the results, it may be concluded that "literature circles" is effective in developing students" abilities to find the theme, main idea, and keywords in a text. Besides, the students pointed out that the implementation of this strategy increased their interest and desire for communication, their self-confidence, cooperative learning, critical thinking, reading objectively without bias, and independent reading skills.
\end{abstract}

Keywords: Reading education, Reading comprehension, Literature circles, Book review, Prospective teacher, Reading desire

\section{Introduction}

As is the case in all walks of life, in education the diversification and change of the tools, methods, and techniques used are inevitable as well. New methods should be searched and tried to improve reading comprehension, which students need most to cope with school courses and increase their reading desire and interest in reading. "In basic education, even small reading groups, which are not based on competition and which do not have the aim of having students grasp what they have read, develop comprehension skills that students need for many years to cope with school courses" (Gutherie et al., 2004). In addition, literature circles reading activities which are used to improve the students' ability to grasp, analyze, and summarize texts and develop their critical and reflective thinking are known to be more effective than traditional text reading activities such as reading the text aloud or silently, guessing unknown words from context and looking them up in the dictionary, analyzing the text using wh- questions, and analyzing the stylistic properties of texts (Briggs, 2010; Daniels \& Steineke, 2004; McElvain, 2010; Wilfong, 2009).

A literature circle is a reading group consisting of 4 or 5 people in which students who have different academic success levels and reading abilities voluntarily come together to read literary texts such as a novel or a story or expository texts such as essays, articles, or textbooks they like and to share their reading experiences with each other (Daniels, 2002; Karatay, 2015). The reason why these reading activities are called literature circle activities is that the order of seating is designed either as a full or half circle which allows all group members to see each other's faces when they come together. If the conversation concerning the text is carried out only by group members, then the order of seating is a full circle (Daniels, 2002). If students other than the group members are asked to participate as audience in the reading activity, the order of seating is arranged as a semi-circle (Karatay, 2015).

In literature circles, all members in the group read the same text, participate in the discussion about the text, and each has a different reading task for the presentation to be made at the end of the discussion. Four of these reading tasks are basic (compulsory) and four of them are optional. The prominent tasks to be performed as compulsory are Questioner, Connector, Literary luminary/Passage master, and Illustrator. When the number of group members is over four, the 
reading tasks such as Summarizer, Researcher, Vocabulary enricher/word wizard and Travel tracer/scene setter are assigned to group members upon their wishes (Daniels, 2002).

After the students create literature circle reading groups, they choose a book or a text determined either by the teacher or by themselves. Each member reads the book or the text in order to do the individual reading task he has been assigned and starts preparation to discuss the task with the members of the group. Each student does this reading activity individually. Independent reading work is performed at school or at home, depending on the volume of the book/text. After the students complete their independent reading work and do their reading tasks, they participate in the discussion about the book and share their experiences with the other students. After the discussion, all students present the work they have prepared which is based on their reading task.

Literature circle reading activities which are done in one class hour for about 40-50 minutes are more effective than traditional reading activities used in the acquisition of skills such as text analysis, making a guess, drawing a conclusion, critical thinking, speaking, writing, enhancing vocabulary, and improving independent reading desire (Briggs, 2010; Daniels \& Steineke, 2004; McElvain, 2010; Wilfong, 2009) because these activities offer students not only a collaborative learning atmosphere for socializing, but assigning a different reading task to each student helps them improve their individual reading skills and learning strategies as well. In this respect, compared with the traditional reading education activities, literature circle reading activities provide students with an indirect learning atmosphere for both socializing and cognitively learning reading comprehension strategies (Briggs, 2010; Burner, 2007; Williams, 2009). Literature circle reading activities are designed to be implemented in four stages:

Preparation: In this stage the introduction of reading tasks, creating literature circles, and choosing the book/text are performed respectively. In the first place, the introduction of reading tasks to the students is implemented. The students are informed individually about what they will do based on the task while reading the book. Secondly, reading circles are created among students who voluntarily want to work together. If those who come together have different interests, skills, and academic achievement levels, this increases the quality of the learning atmosphere and in-class interaction. In the third place, the students are required to choose one of the books/texts offered or one of their choosing.

Individual reading: In this stage, time is given to the students to read the book/text to do their individual reading tasks. In individual reading activities, the students are required to understand the content of the text, take notes, and prepare a presentation to give information about the reading task. For instance, a student who takes over the Illustrator task may be required to draw the chain of events and the characters in the story.

Discussion: In this stage, the student who takes over the Questioner task provides his/her friends with a discussion time for 20-30 minutes to share their feelings and thoughts about the topic of the book, main idea, other messages given in the book, the writer's use of language, and the writer's style of treating the topic. The student also manages the session in a way for all students to participate in the discussion to a considerable extent.

Sharing: In this stage, everybody shares their presentations with their friends about the tasks they have done. For instance, the Literary luminary/Passage master shares the sections s/he likes in the book/text; the vocabulary enricher/word wizard shares the keywords the writer emphasized and the words used with new and different meanings; the Illustrator shares the visuals s/he prepared about the heroes and concept map of the events with the group members (Daniels, 2002; Karatay, 2015).

The purpose of processes of the discussion of the book/text and sharing thoughts about it is to increase the students' comprehension skills about the theme, main idea, supporting ideas, plot and subordinate plots, and the writer's style of treating the topic and events. These processes improve the students' skills of comprehension and analysis of complex texts they will encounter throughout their lives and increase their critical and reflective thinking abilities (Briggs, 2010; Burner, 2007; Burns, 1998). In addition, the processes of preparation and individual reading help students acquire self-control skills for planning and doing independent reading in their reading and learning processes. In terms of cognitive competence, these processes are the stages of the reading comprehension skill that students need in their academic lives.

Literature circles attract students' reading interests more than the traditional reading of literary works and summarizing activities and arouse their reading desire for literary works because the students in literature circles find a collaborative and cooperative social learning atmosphere. In addition to helping students improve their ability to understand the deep structure of texts, this environment contributes to the improvement of students' ability to talk about a literary text, self-confidence, and self-acceptance which even adults even experience difficulty in (Allan, Ellis \& Pearson, 2005). This especially increases the reading desire of male students who are reluctant to do reading because when the students 
themselves determine the amount of reading they will do, this makes them bolder and more eager in the reading process.

For students who participate in literature circles discussions, not only does their reading desire increase, but their vocabulary also improves; reading and analyzing expository and narrative texts the students chose by themselves in literature circles are more effective in improving their vocabulary compared with traditional reading activities (Wilfong, 2009). Besides, it is known that in the reading process, literature circles make students more focused and critical cognitively and help students acquire the responsibility for self-learning and increase their self-confidence (Briggs, 2010; Burner, 2007; Burns, 1998; Daniels, 2002). Based on the results of the experimental study McElvain (2010) conducted with $4^{\text {th }}, 5^{\text {th }}$ and $6^{\text {th }}$ graders, it was determined that the students in the classes which implemented literature circles were more successful in concluding, predicting, and deducing from the texts than the classes that implemented traditional method of reading. In that study, reading instruction in the experimental group continued for 7 months by allocating the first 15 minutes of each lesson for individual reading, 15 minutes for writing conclusions, and 15 minutes for group discussion of the text read by the students. In the comprehension tests administered at the pre-implementation and post-implementation stages, based on the scores of the control and experimental groups, it was determined that there was a significant difference in favor of the experimental group. Additionally, the teachers observed that there was a significant progress in general in the writing and speaking abilities of the experimental group students. These data show that literature circle reading activities not only improve the students' academic success, self-control, and self-confidence in the process of learning and text analysis, but they also improve the students' social skills such as speaking and participating in discussions.

\section{The Purpose of the Study}

In each stage of the teaching process, text analysis and summarizing techniques are taught to improve the students' comprehension skills. Since the techniques taught at schools to improve the students' reading comprehension skills are implemented on short texts, the students are not equipped with necessary skills and also are not experienced enough to understand and analyze long and complex texts. As most of the students have difficulty in focusing on long texts, even though they are prospective teachers, their interests and desires for reading are not at the satisfactory level (Demir Atalay, 2009; Batur, Gülveren \& Bek, 2010). Furthermore, it cannot be asserted that those who acquired the habit of reading at an early age have an interest in reading and that those who have an interest do not have adequate experience and skills to cope with traditional literature classes and to comprehend and analyze a literary text. Prospective teachers, even in their final year of study, still cannot acquire adequate experience and skills to comprehend the main theme and idea in long and complex texts (Karatay, 2007). In this study, the effect of literature circles on the students' ability to analyze texts, their reading desires, and interests in reading was studied. Thus, this study aimed to answer the following questions.

\section{The Problem Sentence of the Study}

Are literature circles effective on increasing the students' ability to analyze texts, their desires for independent reading, and their interests in reading?

\subsection{Sub-problems}

(1) Are literature circles effective on improving the students' ability to find the topic, main idea, and keywords in a text?

(2) Are literature circles effective on increasing the students' desires for independent reading and interests in reading?

\section{Research Design and Method}

The study was designed as action research. This kind of research aims to present systematic data about studies which are pre-planned, arranged, and based on collaboration to increase the quality of life and education through critical reflection and reasoning (Bogdan \& Biklen, 1998; Johnson, 2002; Mills, 2014). In these studies, the aim is not only understanding the behaviors and point of views of the people investigated, but also improving and changing them (Büyüköztürk, Çakmak, Akgün, Karadeniz \& Demirel, 2011; Ekiz, 2003). Cohen, Manion \& Morrison (2007, p. 307) defines action research and its steps as follows: "Action research works on and tries to solve real, practitioner identified problems of everyday practice, is collaborative and builds in teacher involvement, seeks causes and tries to work on those causes, plans an intervention by the practitioners themselves, implements the intervention, and evaluates the success of the intervention in solving the identified problem." In this study, too, the effect of literature circle reading activities on the students' text analysis skills and independent reading desires and interests in reading were studied, and the data were given to the related parties to make reading education lessons more attractive and 
functional. The research was planned in three stages: In the first stage, Reading Comprehension Test (henceforth, RCT) version 1.1 was used to determine the students' text analysis skills of finding the theme, main idea, and keywords (Karatay, 2013, p. 246). In the second stage, for 12 weeks, one hour of every 4 hour traditional reading classes was reserved for literature circles reading activities. In the third stage, RCT version 1.1 was used again at the end of the term to measure the improvement in the students' text analysis skills. Also, to obtain detailed data about the students' book reading experiences and their views about the quality of implementation, the students' views were obtained. To that end, the students were asked two open-ended questions which were, "What did you like and did not like about literature circle reading activities?" and "What suggestions can you make to improve the implementation of literature circles?" As response to these open-ended questions, the students stated their views in written form. Thus, by using both quantitative and qualitative research methods together, methodological triangulation was done to determine the effect of literature circle reading activities on the students' text analysis skills, their desire for independent reading, and their interests in reading.

\subsection{Study Group}

The study group of the research consisted of a total of 92 third-year students in two sections in the department of Turkish Education. 36 students (39\%) were male and $56(61 \%)$ were female. The participants in the sample were selected using homogenous sampling. Etikan, Musa, Elkassim (2016, p. 3) define homogenous sampling as a form of sampling that "focuses on candidates who share similar traits or specific characteristics. For example, participants in Homogenous Sampling would be similar in terms of ages, cultures, jobs or life experiences. The idea is to focus on this precise similarity and how it relates to the topic being researched." In the sampling process, all third year students who were taking the course were included in the sample. In Turkey, as prospective teachers are selected through a central exam, all teacher candidates share similar characteristics.

\subsection{Implementation Process}

Literature circles reading activities were planned to enhance the learning atmosphere in the reading education classes and to encourage collaboration among the students and support their acquisition of text analysis strategies. In the first week of the 14-week Reading Education course, RCT version 1.1 was administered to determine the students' initial levels of reading comprehension. Additionally, in the first week, by doing brainstorming, the writers and texts the students liked were determined. A list of 20 books which the students wanted to read was prepared. In the second week, a briefing on literature circles and reading tasks was given to the students, and a sample implementation on short reading texts with reading groups of 3 or 4 people were made. During this practice session, the students were given guidance on independent reading, having discussions, reading tasks, and the presentations they would prepare. Thus, they were given a safe and sheltered introduction to reading longer texts confidently. After the second week, every week the students selected a book they wanted from the designated reading list, voluntarily set up their own reading groups, and decided on the assignment of the reading tasks among themselves. During the remaining 12 weeks of the reading course, the groups selected a book they wanted every week, conducted independent reading at home, discussed the book in the class, and shared their presentations about it with others. In the final exam given at the end of the semester, RCT version 1.1 was administered once again to determine to what extent the students had progressed. In addition, the students' views about the implementation of the study were taken, using two open-ended questions about literature circles reading activities.

\subsection{Data Collection Tools}

RCT version 1.1 was developed by Karatay (2007) and reliability and validity studies of the test were conducted and later published by Karatay (2013). The type of the text in the test is expository. The number of the words in the text is 1974. There are 25 multiple choice items about the text in the comprehension test. Items 1-23 are about the keywords included in the text. Item 24 is about the topic studied and item 25 is about the main idea. In the first implementation of the RCT, Cronbach alpha (reliability coefficient) was calculated as 0,82 . In the second implementation, the reliability coefficient was calculated as 0,84 . These data showed that reading comprehension test version 1.1 was reliable for collecting data in the study. The data collected through the RCT version 1.1. formed the quantitative part of the data collection process.

In addition to the quantitative data, qualitative data were also collected in this study. The latter type of data were obtained through the written answers students gave to respond to the two open-ended questions that were directed to the students at the end of the 12-week implementation process. 


\subsection{Data Analysis}

In the analysis of the data obtained through the RCT version 1.1, mean, standard deviation, repetitive measurements, and t-test were used. The responses the students gave to answer the open-ended questions were analyzed through content analysis technique which is commonly used in qualitative research studies. Each student's answers to the open-ended questions about the implementation were examined, and the identical, similar, and different opinions were coded under main-themes and sub-themes. This coding method is defined as a systematic and innovative technique in which some words in a text are summarized under smaller content categories (Büyüköztürk et al., 2011). Thus, the students' views about the implementation were classified into main themes and sub-themes, and each student's response was coded as Participant1 (henceforth, P1), P2, P3 ... In this process, when it was not apparently clear to determine under which theme or sub-theme the students' opinions would be categorized, the opinions of an expert in the field were sought. The data obtained from the participants about the implementation through content analysis were then transformed into tables, using their frequencies and percentages to express the students' opinions in numerical form.

\section{Findings}

In this section, the change in the students' text analysis skills at the end of the 12-week literature circles reading activities and the content analysis of the students' opinions on literature circles are presented.

5.1 The First Sub-problem: In the analysis of this problem, the arithmetic averages of the pre-test and post-test scores of the answers the students gave to the questions about the topic, main idea, and keywords in RCT version 1.1 which were administered before and after literature circles reading activities were used. The data about these are given in Table 1.

Table 1. The students' results of the pre-test and post-test scores in text analysis

\begin{tabular}{lllccccc}
\hline Text analysis & Implementation & $\mathrm{N}$ & $\overline{\mathrm{X}}$ & $\mathrm{S}$ & $\mathrm{Sd}$ & $\mathrm{t}$ & $\mathrm{p}$ \\
\hline \multirow{2}{*}{ 1. Theme } & 1. Pre-test & 92 & 59,89 & 4,18 & \multirow{2}{*}{183} & \multirow{2}{*}{5,952} &, 000 \\
& 2. Post-test & 92 & 89,67 & 2,35 & & & \\
\multirow{2}{*}{ 2. Main idea } & 1. Pre-test & 92 & 62,50 & 3,51 & & & \\
& 2. Post-test & 92 & 72,50 & 3,36 & & 1,973 &, 050 \\
\multirow{2}{*}{ 3. Keywords } & 1. Pre-test & 92 & 53,15 & 3,64 & & & \\
\multirow{2}{*}{ 4. Reading } & 2. Post-test & 92 & 78,26 & 3,25 & 183 & 4,928 &, 000 \\
comprehension & 1. Pre-test & 92 & 58,51 & 3,40 & & & \\
& 2. Post-test & 92 & 80,14 & 2,28 & 183 & 5,055 &, 000 \\
\hline
\end{tabular}

$* \mathrm{p}<, 05$ significant difference.

When Table 1 was examined, it was seen that the students' post-test scores $(89,67)$ in finding "the theme in the text" were higher than their pre-test scores $(59,89)$. It was seen that there was a significant difference in favor of the post-test between the scores of the pre-test and post-test $\left[\mathrm{t}_{(183)}=5,952, \mathrm{p}<, 000\right]$ in the students' ability to find "the theme in the text". It can be said that literature circles are effective in improving the students' ability to find "the theme in the text".

Similarly, the students' post-test scores $(72,50)$ in finding "the main idea in the text" were higher than their pre-test scores $(62,50)$. It was seen that there was a significant difference in favor of the post-test between the scores of pre-test and post-test $\left[\mathrm{t}_{(183)}=1,973, \mathrm{p}<, 050\right]$ in the students' ability to find "the main idea in the text". Thus, it can be concluded that literature circles are effective in improving the students' ability to find "the main idea in the text".

Similar findings can be said also about the students' ability to find "the keywords in the text". The students' post-test scores $(78,26)$ in finding "the keywords in the text" were higher than their pre-test scores $(53,15)$. It was seen that there was a significant difference in favor of the post-test between the scores of pre-test and post-test $\left[\mathrm{t}_{(183)}=4,928, \mathrm{p}<, 000\right]$ about students' ability to find "the keywords in the text". Therefore, it can be stated that literature circles are effective in improving the students" ability to find "the main idea in the text".

The pre-test scores $(58,51)$ of the reading comprehension skills of the students were also lower than their post-test scores $(80,14)$. It was determined that there was a significant difference in favor of the post-test between the scores of pre-test and post-test $\left[\mathrm{t}_{(183)}=5,055, \mathrm{p}<, 000\right]$ in the students' "reading comprehension" ability. Using this finding, it may be concluded that literature circles are effective in improving the students" "reading comprehension" ability. 
5.2 The Second Sub-problem: The analysis of this problem was conducted, using content analysis of the answers the students gave to the open-ended questions about the implementation of literature circles reading activities. After literature circles reading activities that lasted an-hour-a-week for 12 weeks, the students' views about their implementation were determined under positive (4), negative (1) and suggestion (1) themes. The data about this are given in Table 2.

Table 2. Providing a social learning atmosphere

\begin{tabular}{|c|c|c|c|c|}
\hline No & Views & Participants & $\mathrm{N}$ & $\%$ \\
\hline 1 & $\begin{array}{l}\text { Literature circles improved our ability } \\
\text { to initiate communication }\end{array}$ & $\begin{array}{l}\text { P1-P2-P3-P4-P5-P6-P7-P9-P10-P11-P15-P17-P18- } \\
\text { P19-P20-P21-P22-P23-P24-P28-P29-P30-P32-P33- } \\
\text { P34-P35-P36-P37-P39-P40-P41-P42-P48-P50-P51- } \\
\text { P52-P53-P55-P57-P59-P60-P62-P63-P64-P65-P66- } \\
\text { P67-P68-P69-P70-P71-P72-P74-P75-P77-P79-P80- } \\
\text { P81-P82-P83-P85-P87-P88-P90-P86-P90. }\end{array}$ & 68 & 74 \\
\hline 2 & $\begin{array}{l}\text { Literature circles provided a hands-on } \\
\text { atmosphere for learning book } \\
\text { reviewing and book discussion. }\end{array}$ & $\begin{array}{l}\text { P8-P9-P25-P28-P35-P42-P48-P51-P53-P58-P59-P60 } \\
\text {-P61-P62-P63-P65-P72-P73-P74-P75-P76-P77-P78- } \\
\text { P79-P83-P85-P86. }\end{array}$ & 27 & 32 \\
\hline 3 & $\begin{array}{l}\text { Literature circles were beneficial both } \\
\text { culturally and educationally. }\end{array}$ & $\begin{array}{l}\text { P1-P2-P3-P12-P42-P54-P67-P69-P84-P85-P86-P90- } \\
\text { P91-P92. }\end{array}$ & 14 & 16 \\
\hline 4 & $\begin{array}{l}\text { I will also use literature circles when I } \\
\text { become a teacher. }\end{array}$ & $\begin{array}{l}\text { P7-P8-P11-P37-P60-P61-P64-P65-P67-P69-P72-P76 } \\
\text { - P79- P90. }\end{array}$ & 14 & 16 \\
\hline
\end{tabular}

Literature circles provided the students with a social learning atmosphere. 68 students (74\%) stated that literature circles "improved their ability to communicate". In addition to improving their ability to communicate, 27 students (32\%) stated that literature circles "provided an atmosphere for learning book reviewing and book discussion." Besides, 14 students (16\%) stated that literature circles "were beneficial both culturally and educationally", and 14 students (16\%) stated that "they would also use literature circles when they became teachers." As understood from these data, the students regarded literature circles as a social learning atmosphere for communicating with each other and learning together. Moreover, literature circles provided them with a hands-on, concrete learning experience about book reviewing and book discussion. The prospective teachers who thought literature circles were beneficial both culturally and educationally stated that literature circles were an effective teaching strategy and added that they would use them when they became teachers.

Table 3. Improving critical reading

\begin{tabular}{|c|c|c|c|c|}
\hline No & Views & Participants & $\mathrm{N}$ & $\%$ \\
\hline 1 & $\begin{array}{l}\text { Literature circles provided us with an } \\
\text { opportunity to read and assess many } \\
\text { books from different perspectives. }\end{array}$ & $\begin{array}{l}\text { P1-P2-P4-P8-P9-P10-P11-P13-P14-P15-P16-P19- } \\
\text { P20-P21-P22-P23-P24-P25-P26-P27-P31-P32-P33- } \\
\text { P34-P35-P38-P39-P41-P48-P51-P53-P57-P59-P60- } \\
\text { P61-P62-P63-P65-P66-P68-P71-P72-P73-P75-P76- } \\
\text { P77-P79-P81-P83-P84-P88-P90. }\end{array}$ & 52 & 57 \\
\hline 2 & $\begin{array}{l}\text { In literature circles, we read and } \\
\text { reviewed the books of authors who had } \\
\text { different world views than us. }\end{array}$ & P2-P3-P4-P55-P57-P60-P62-P63-P65-P66-P70-P72 & 12 & 13 \\
\hline 3 & $\begin{array}{l}\text { What was told in the books we read in } \\
\text { literature circles helped us overcome } \\
\text { our prejudices against some historical } \\
\text { figures. }\end{array}$ & P1-P5-P2-P27-P31-P32-P66-P70-P72-P83 & 10 & 11 \\
\hline
\end{tabular}


According to 52 students (57\%), literature circles "provided them with an opportunity to read and assess many books from different perspectives"; 12 students (13\%) said that "in literature circles, they read and reviewed the books of authors who had different world views than themselves", and 10 students (11\%) stated that "what was told in the books they read in literature circles helped them overcome their prejudices against some historical figures." These data show that the students' critical reading abilities about knowledge, event, situation, and characters in the books improved. The fact that the students analyzed the books all together but did different tasks and from different perspectives and held discussions afterwards improved their ability to assess what was told in the books without having prejudices and having different point of views.

Table 4. Improving independent reading desire and interest in reading

\begin{tabular}{llllc}
\hline No & Views & Participants & $\mathrm{N}$ & $\%$ \\
\hline \multirow{2}{*}{1} & $\begin{array}{l}\text { Literature circles aroused the desire and } \\
\text { interest in getting to know the other } \\
\text { books by the same author, different }\end{array}$ & P3-P11-P17-P26-P27-P28-P30-P31-P32-P33-P35-P3 & 7-P68-P70-P72-P74-P76-P60-P62-P64-P65-P66-P67 & 35 \\
authors, and different literary genres. & P81-P82-P84-P85-P90. & & 38
\end{tabular}

The fact that literature circles were

2 implemented in a conversational atmosphere provided enjoyment.

P1-P7-P11-P37-P40-P47-P55-P56-P64-P71-P75-P76 $-\mathrm{P} 77-\mathrm{P} 83$
14 15

35 students (38\%) stated that literature circles "aroused the desire and interest in in getting to know the other books by the same author, different authors, and different literary genres" and 14 students (15\%) said that "the fact that literature circles were implemented in a conversational atmosphere provided enjoyment." As can be understood from these data, book discussions in the literary circles activities activated the students' desire to participate in them socially and to express their opinions. This increased the students' desire to read books independently and their interest in reading. It was understood that reading books as a group and holding discussions about them afterwards and talking about them was more enjoyable than individual book reading. Moreover, it was observed that these kinds of reading activities not only reinforced the existing reading habits of the students, but encouraged those who didn't have the habit of reading to reading books as well.

Table 5. Improving speaking ability and self-confidence

\begin{tabular}{|c|c|c|c|c|}
\hline No & Views & Participants & $\mathrm{N}$ & $\%$ \\
\hline 1 & $\begin{array}{l}\text { Literature circles enabled us to express } \\
\text { our feelings and thoughts about a topic or } \\
\text { a work with self-confidence and more } \\
\text { effectively. }\end{array}$ & $\begin{array}{l}\text { P1-P3-P4-P5-P9-P10-P16-P27-P34-P35-P37- } \\
\text { P38-P39-P40-P48-P49-P55-P56-P59-P60-P65- } \\
\text { P71-P82-P83. }\end{array}$ & 24 & 26 \\
\hline 2 & $\begin{array}{l}\text { Literature circles enabled us to create a } \\
\text { quality conversation atmosphere. }\end{array}$ & P4-P63-P81-P88. & 4 & 4 \\
\hline 3 & $\begin{array}{l}\text { Literature circles made it possible for } \\
\text { students who had never participated in } \\
\text { classes to take part in classes. }\end{array}$ & P4-P24 & 2 & 2 \\
\hline 4 & $\begin{array}{l}\text { Focusing on different aspects related to } \\
\text { the topic provided us with relief }\end{array}$ & P9-P36 & 2 & 2 \\
\hline
\end{tabular}

24 students (26\%) stated that literature circles "enabled them to express their feelings and thoughts about a topic or a work with self-confidence and more effectively"; 4 of them (4\%) stated that literature circles "enabled them to create a quality conversation atmosphere"; 2 students (2\%) stated that "literature circles made it possible for students who had never participated in classes to take part in classes"; and 2 students (2\%) stated that "focusing on different aspects related to the topic provided them with relief." These data show that literature circles improved the students' ability to share their feelings and thoughts about a topic with self-confidence and effectively in front of a group or with each 
other. Another important point is that through this strategy, students who never express their opinions begin to participate in classes. In addition, students' doing different activities other than the routine course of the classes relieved the students.

Table 6. Negative situations encountered in literature circles

\begin{tabular}{|c|c|c|c|c|}
\hline No & Views & Participants & $\mathrm{N}$ & $\%$ \\
\hline 1 & $\begin{array}{l}\text { Some students did not make } \\
\text { sufficient preparation since } \\
\text { they had not read the book. }\end{array}$ & $\begin{array}{l}\text { P7-P25-P39-P40-P46-P49-P49-P52-P55-P53-P63-P69- } \\
\text { P72- P80-P87-P89 }\end{array}$ & 16 & 17 \\
\hline 2 & $\begin{array}{l}\text { Sometimes views were not } \\
\text { shown respect during } \\
\text { discussions }\end{array}$ & P2-P22-P63-P83 & 4 & 4 \\
\hline 3 & $\begin{array}{l}\text { Some students talked } \\
\text { unnecessarily much and } \\
\text { some talked too little. }\end{array}$ & P17-P40-P44 & 3 & 3 \\
\hline 4 & $\begin{array}{l}\text { Sometimes the students } \\
\text { couldn't hear each other's } \\
\text { voices as there was too much } \\
\text { noise in the class. }\end{array}$ & P5-P21 & 2 & 2 \\
\hline 5 & $\begin{array}{l}\text { Since the number of the } \\
\text { books to read was too many } \\
\text { and the time for reading was } \\
\text { too little, the students } \\
\text { hurried while reading and } \\
\text { couldn't enjoy the book. }\end{array}$ & P6-P16 & 2 & 2 \\
\hline
\end{tabular}

16 students (17\%) said "some students didn't make sufficient preparation since they hadn't read the book"; 4 students (4\%) said "sometimes views were not shown respect during discussions"; 3 students (3\%) said "some students talked unnecessarily much and some talked too little"; 2 students (2\%) said "sometimes we couldn't hear each other's voices because there was too much noise in the class"; and 2 students (2\%) stated that "since the number of the books to read was too many and the time for reading was too little, they hurried while reading and couldn't enjoy the book".

These data are about general problems in the implementation of literature circles. That some of the students in the group did not read the book or that they took an easy route and made their preparation, using the summary of the book easily found on the internet, prevented them from participating fully in the discussions. Two other problems were the disagreements caused by differences in political views and cultural backgrounds among group members and students' showing disrespect to each other's views. The teacher should control this tense atmosphere that could emerge among the students and be careful to create a climate of respect and tolerance. Making videos of discussion groups and having students watch instances of such behaviors and become aware of them is known to be an effective strategy to solve this problem (Clarke \& Holwadel, 2007).

Another problem is that in book discussions students who have dominant characters talk too much and those who have timid characters talk little. Because of this, the teacher or the moderator, to manage the discussion, should set the rules for participation at the very beginning and give equal right to speak to everyone. Book discussions sometimes could lead to too much noise in the classroom. This may lead to class management problems and lower the quality of book discussions. The teacher's walking about in the class and asking questions to students is a strategy that could reduce this noise.

Because the workload in other courses is intense or some students do not have the habit of reading, their reading speed and interests in reading could be lower. In this case, one week reading time could not be enough for them. The students reported that because of those reasons, they sometimes hurried while reading and could not enjoy the books. It is usual to experience such problems in crowded classes that consist of 45-50 students and in classes which are complex in terms of the students' interests, abilities, and academic success levels. It was observed that for university students choosing a book about 150-200 pages to read in one week was more reasonable. 
Table 7. Suggestions about literature circles

\begin{tabular}{lllcc}
\hline No & Views & Participants & N & $\%$ \\
\hline 1 & $\begin{array}{l}\text { Literature circles should be given time } \\
\text { apart from reading education classes } \\
\text { and be made widespread. }\end{array}$ & $\begin{array}{l}\text { P3-P4-P5-P6-P7-P8-P13-P16-P18-P30-P31-P32-P45-P } \\
\text { 47-P49-P58-P60-P61-P62-P64-P67-P69-P74-P78. }\end{array}$ & 24 & 26 \\
2 & $\begin{array}{l}\text { Reviews about the book being read } \\
\text { should also be reviewed. }\end{array}$ & P3-P4-P5-P6-P7-P8-P30-P31-P32-P45-P58-P68-P90. & 13 & 14 \\
\hline
\end{tabular}

24 students (26\%) said that "Literature circles should be given time apart from reading education classes and be made widespread" and 13 students (14\%) said that "Reviews about the book being read should also be reviewed". The students thought that since literature circles contributed to their personal development educationally and culturally, they should be given extra time apart from the regular reading classes and be made widespread. The students suggested that before discussions those who are assigned the roles of "Summarizer", "Questioner", and "Connector" should make visual presentations about the book and its author and that reviews about both should be analyzed.

\section{Conclusion and Discussion}

The results of this study showed that literature circles contributed to the students' reading comprehension ability in six areas. The first of those is the contribution of literature circles to the students' text analysis skills. It was determined that literature circles were effective in improving the students' text analysis skills such as finding the theme, main idea, and keywords in a text. The data show that reading strategies which were taught through traditional reading education could be realized in a more entertaining and attractive social learning atmosphere through literature circles. The views obtained from the students and the findings of other studies support this conclusion (Briggs, 2010; Burner, 2007; Burns, 1998; Daniels \& Steineke, 2004; McElvain, 2010; Wilfong, 2009).

The second contribution of literature circles is their providing students with a social learning atmosphere. The students in this study pointed out that literature circles provided them with "a quality educational and cultural atmosphere" that could help them develop their skills of interpersonal communication, critical reading, and book reviewing. Besides, unlike theoretical lessons, literature circles provided them with a hands-on concrete learning experience about book reviewing, book discussions, and a teaching model for their teaching careers.

The third contribution of literature circles to students is their effect on improving the students' ability to read texts critically. The views of the students such as "literature circles provided us with an opportunity to read and assess many books from different perspectives"; "in literature circles, we read and reviewed the books of authors who had different world views than us"; and "what was told in the books read in literature circles helped us overcome our prejudices against some historical figures" support this. The fact that the students read and analyzed the books doing different tasks and then talked about them altogether in literature circles shows that they improved their ability to assess the content of a book without prejudice and by using different perspectives.

The fourth contribution of literature circles is that they improve the students' independent reading desires and interests in reading. Literature circles increase the reading motivation of the students who are reluctant and indifferent to reading. The book discussions in literature circles activate the students' desire for participation in discussions and stating their opinions socially. This situation increases their desire and interest for independent reading. In this study it was understood that reading a book as a group and talking about it afterwards was more enjoyable than individual reading. Moreover, it was observed that literature circle activities not only reinforced the students' existing reading habits but also turned those who didn't have the habit of reading into more interested, more willing, and self-confident individuals when it came to reading. This finding of the study corroborates the findings of similar other studies conducted at different times (Allan, Ellis \& Pearson, 2005; Certo, Moxley \& Miller, 2010).

The fifth contribution of literature circles is that they improve the students' speaking abilities and self-confidence. Literature circles improve the students' speaking abilities and self-confidence for effective presentations. The views of the students such as "literature circles enabled us to express our feelings and thoughts about a topic and a work with confidence and more effectively" and "literature circles made it possible for students who had never participated in classes to take part in classes" are evidence to this, and they also confirm the findings of similar studies in the literature (McElvain, 2010; Wilfong, 2009).

The final contribution of literature circles is that they were instrumental in developing tolerance towards cultural and socio-economic differences. That the students who came from different cultures and socio-economic backgrounds 
displayed progress and improvement in their efforts to establish interpersonal communication with each other is a finding of this study that supports this conclusion.

Problems encountered in similar studies such as "some students did not read the book"; "some students did not show respect to each other during discussions"; "some students talked unnecessarily much and some talked too little"; and "sometimes there was too much noise in the class" were also found in this study. However, when the benefits of literature circles are considered on the whole, these problems could be minimized by taking some precautions. For instance, for students whose motivation is lower, literature circles can be created with books and texts that are not voluminous. Likewise, recording the videos of discussions in which students cross the boundaries of mutual respect and having students watch those would be effective for students to notice unacceptable behaviors (Clarke \& Holwadel, 2007).

The students quite liked the implementation of literature circles which supported their reading education classes and which was conducted to make the reading classes more enjoyable. The students thought that literature circles should be given a time of their own and be made widespread since they provided support for their educational, cultural, and personal development. Literature circles stimulated the students' desire to communicate with each other, developed their text analysis skills to actively read and participate in class discussions, aroused their independent reading desires and interests in reading, and developed their self-confidence in speaking. The results of this study on the effect of literature circles show that book discussions held as different from traditional book reading activities make the reading process more entertaining and more conscious.

\section{References}

Allan, J., Ellis, S., \& Pearson, C. (2005). Literature circles, gender and reading for enjoyment. Report for The Scottish Executive Education Department. http://www.scotland.gov.uk/Resource/Doc/930/0021345.pdf

Batur, Z., Gülveren, H. \& Bek, H. (2010). Öğretmen adaylarının okuma alışkanlıkları üzerine bir araştırma: uşak eğitim fakültesi örneği, Uşak Üniversitesi Sosyal Bilimler Dergisi, 3(1), 32-49. https://doi.org/10.12780/UUSBD61

Bogdan, R. C., \& Biklen, S. K. (1998). Qualitative research for education: an introduction to theory and methods. Needham Heights, MA: Allyn and Bacon, Inc.

Briggs, S.R. (2010). Using literature circles to increase reading comprehension in third grade elementary students. (Submitted in Partial Fulfillment of the Requirements for the Degree Master of Science in Education), San Rafael, CA.

Burner, K. J. (2007). The effects of reflective and reflexive writing prompts on students' selfregulation and academic performance. ( $\mathrm{PhD}$ dissertation), Florida State University, Tallahassee.

Burns, B. (1998). Changing the classroom climate with literature circles. Journal of Adolescent and Adult Literacy, 42 (2), 124-129.

Büyüköztürk, Ş., Çakmak, E.K., Akgün, Ö.E., Karadeniz, Ş., \& Demirel, F. (2011). Bilimsel araşttrma yöntemleri. $\left(10^{\text {th }}\right.$ ed $)$, Ankara: Pegem Academy.

Certo, J., Moxley, K., Reffitt, K., \& Miller, J. A. (2010). I learned how to talk about a book: children's perceptions of literature circles across grade and ability levels. Literacy Research \& Instruction, 49(3), 243-263. https://doi.org/10.1080/19388070902947352

Clarke, L. W., \& Holwadel, J. (2007). Help! What Is Wrong With These Literature Circles and How Can We Fix Them?. Reading Teacher, 61(1), 20-29. https://doi.org/10.1598/RT.61.1.3

Cohen, L., Manion, L., \& Morrison, K. (2007). Research methods in education. (6 $6^{\text {th }}$ ed), Routledge, Taylor and Francis Group, New York. https://doi.org/10.3108/beej.10.r1

Daniels, H., \& Steineke, N. (2004) Mini-lessons for literature circles. Portsmouth, NH: Heinemann.

Daniels, H. (2002). Literature circles voice and choice in book clubs and reading groups. $\left(2^{\text {nd }} \mathrm{ed}\right)$, Markham, Ontario: Pembroke Publishers Limited.

Demir Atalay, T. (2009). İlköğretim II. kademe öğretmen adaylarının okuma alışkanlıkları üzerine bir araştırma (gazi üniversitesi örneği). Turkish Studies International Periodical For the Languages, Literature and History of Turkish or Turkic, (4) 3, 717-745.

Ekiz, D. (2003). Eğitimde araştırma yöntem ve metodlarına giriş. Ankara: Anı Publishing. 
Etikan, I., Musa, S. A., \& Alkassim, R. S. (2016). Comparison of convenience sampling and purposive sampling. American Journal of Theoretical and Applied Statistics, 5(1), 1-4. https://doi.org/10.11648/j.ajtas.20160501.11

Gutherie, J.T., Wigfield, A., Barbosa, P., Perencevich, K.C., Taboada, A., Davis, M.H., Scafiddi, N.T., \& Tonks, S. (2004). Increasing reading comprehension and engagement through concept-oriented reading instruction. Journal of Education Psychology, 96 (3), 403-423. https://doi.org/10.1037/0022-0663.96.3.403

Johnson, A. P. (2002). A short guide to action research. Boston: Allyn \& Bacon.

Karatay, H. (2007). İlköğretim Türkçe öğretmeni adaylarının okuduğunu anlama becerileri üzerine alan araştırması. ( $\mathrm{PhD}$ dissertation), Ankara: Gazi Üniversitesi, Eğitim Bilimleri Enstitüsü.

Karatay, H. (2013). Okuma eğitimi kuram ve uygulama. ( $2^{\text {nd }}$ ed), Ankara: Pegem Academy.

Karatay, H. (2015). Eleştirel düşünme ve okuma alışkanlığı becerilerinin geliştirilmesi için edebiyat halkası: kitap eleştirisi modeli. Millî Eğitim, 208, 1-17.

McElvain, C. (2010). Transactional literature circles and the reading comprehension of English learners in the mainstream classroom. Journal of Research in Reading, 33(2), 178-205. https://doi.org/10.1111/j.1467-9817.2009.01403.x

Mills, G. E. (2014). Action research. a guide for the teacher researcher. Boston: Boston Pearson, Inc.

Wilfong, L. G. (2009). Textmasters: bringing literature circles to textbook reading across the curriculum. Journal of Adolescent \& Adult Literacy, 53(2), 164-171. https://doi.org/10.1598/JAAL.53.2.7

Williams, S. M. (2009). The impact of collaborative, scaffolded learning in $K-12$ schools: A meta-analysis. Los Angeles: Metiri Group.

\section{List of books read in literature circles}

Atılgan, Y. (2007). Aylak adam. İstanbul: Yapı Kredi Publishing.

Aytmatov, C. (2014). Toprak ana. İstanbul: Ötüken Publishing.

Aytmatov, C. (2016). Beyaz gemi. İstanbul: Ötüken Publishing.

Ayvazoğlu, B. (2013). Yahya Kemal: eve dönen adam. İstanbul: Kapı Publishing.

Ayvazoğlu, B. (2015). Aşk estetiği. İstanbul: Kapı Publishing.

Bakiler, Y.B. (2012). Türkistan Türkistan. İstanbul: Yakın Plan Publishing.

Bakiler, Y.B. (2012). Üsküp’ten Kosova'ya. İstanbul: Yakın Plan Publishing.

Coelho, P. (2015). Simyact. İstanbul: Can Publishing.

De Vasconcelos, J. M (2016). Şeker portakalı. İstanbul: Can Publishing.

Goethe, J.W (2016). Genç Werther'in acıları. İstanbul: Can Publishing.

Hesse, H. (2015). Siddhartha. İstanbul: Can Publishing.

Meriç, C. (2004). Bu ülke. İstanbul: İletişim Publishing.

Meriç, C. (2004). Mağaradakiler. İstanbul: İletişim Publishing.

Orwell G. (2016). Hayvan çiftliği. İstanbul: Can Publishing.

Pala, İ. (2016). Od. İstanbul: Kapı Publishing.

Pala, İ. (2016). Şah ve sultan. İstanbul: Kapı Publishing.

Pamuk, O. (2013). Kar. İstanbul: Yapı Kredi Publishing.

Petrov, G. (2016). Beyaz zambaklar ülkesinde. İstanbul: İskele Publishing.

Safa, P. (2016). Matmazel Noralya'nın koltuğu. İstanbul: Alkım Kitabevi Publishing.

Şafak, E. (2011). İskender. İstanbul: Doğan Kitap Publishing. 